\title{
WATER RIGHTS \\ IN THE COAL FIELDS OF THE YELLOWSTONE RIVER BASIN
}

\author{
WILLIAM H. VEEDER*
}

\begin{abstract}
Here there was no water for the people to drink.
2. They quarreled therefore with Moses...

4. So Moses cried out to the Lord, "What shall

I do with this people? A little more and they

will stone me!"
\end{abstract}

- Exodus 17:1-4

There is a deadly contest being wages in and around the coal fields of the Yellowstone River Basin of southeastern Montana and northeastern Wyoming. That struggle does not relate primarily to the vast coal deposits of the region but rather to control of the insufficient water supplies of the Yellowstone River and its principal tributaries. If the thirty-four billion tons of strippable coal deposits ${ }^{1}$ are to be used to alleviate the energy crisis, a solution must be found to the question of the distribution of water resources in the area.

Ultimately, the formidable body of law pertaining to water rights in the Yellowstone River Basin will control. At the moment, however, law and logic are being overwhelmed by politics, which mixes readily with coal and water to create a volatile combination. Montana and Wyoming have major stakes in the anticipated development. ${ }^{2}$ It is from Montana and Wyoming that the waters primarily flow. Farmers and cattlemen in the area asserting rights in the streams pursuant to state law are gravely threatened by a possible invasion of those rights. Federal policies, agencies, and water rights are often in conflict with the policies and agencies of the states and the rights of those claiming under the states. Moreover, the fact that the Bureau of Reclamation has entered into contracts with the major energy companies for the sale of water rights $^{3}$ has sparked an interagency dispute, presaging almost unlimited con-

\footnotetext{
* Bureau of Indian Affairs, Department of the Interior. The views expressed herein are those of the author and do not purport to represent the policies of any governmental entity.

1. U.S. Dep't of the INterlor, Bureau of Reclamation, Appraisal Report on Montana-Wyoming Aqueducts 13 (1972). See generally Smith. The Wringing of the West, Washington Post, Feb. 16, 1975, $\$$ B, at 1, col. 1; Josephy, Ripping Coal From the Northern Plains, Washington Star-News, July 29, 1973, § C, at 2, cols. $1-5$.

2. The area involved is "one of very low population, rural population averaging 1.4 persons per square mile. Urban population accounts for almost half the total of over 68,000 persons." See RePort on MoNTana-Wyomixg AQueducts, supra note 1.

3. See Memorandum from Morris Thompson, Commissioner of Indian Affairs to Rogers C.B. Morton, Secretary of the Interior. Feb. 24. 1975.
} 
flicts among all the holders of rights to the use of water, irrespective of their source of title. Most gravely threatened by the water crisis and interagency struggles are the Indians who occupy Montana's Crow and Northern Cheyenne Indian Reservations and Wyoming's Arapahoe and Shoshone Tribes of the Wind River Reservation. In order to formulate an appropriate policy for the control of water rights in the coal fields of the Yellowstone Basin it is essential to understand the development and implications of conflicting federal, state, and Indian claims.

\section{I}

The Development of Federal and Western Water law

In 1496 Henry VII of England commissioned John Cabot to discover and claim on behalf of His Majesty all lands not otherwise claimed or occupied by "Christian" princes. From Cabot's voyages stem the British, and later the American, claims to the lands and waters of this continent. ${ }^{4}$ Confronted by powerful tribes, ${ }^{5}$ the British Crown and other European potentates were forced to enter into treaties with the Indians. These treaties acknowledged the Indians' rights of occupancy and self-government. Among themselves the European powers recognized each other's rights to obtain the Indians' lands by purchase or conquest, ${ }^{6}$ Similar rights were asserted by France to the lands west of the Mississippi. ${ }^{?}$

Following independence, the United States reaffirmed these principles ${ }^{8}$ and coupled them with a specific division of powers between the state and

4. In Johnson \%. McIntosh, Chief Justice Marshall, reviewing this nation's laws respecting the claims to Indian lands, described as an "extravagant" pretension the proposition that by sailing down the Virginia coast Cabot had claimed for the King all the lands which came within his view. "To this discovery the English trace their title." 21 U.S. (8 Wheat.) 543, 576 (1823). This claim was also recognized as preposterous by Chief Justice Story who scoffed at the idea that an alleged "discovery" of inhabited lands could serve as a basis for asserting title to it. Rather, Story recognized the claim for what it was and is-an assertion of European bias against native peoples in general. 1 J. Story, Commentaries on the Constitution $\$ 152$, at 106 (5th ed. 1891). And throughout the early decades of American history, as Chancellor Kent remarked, the non-Indian settlers were "penetrated with a perfect contempt of Indian rights." 3 J. KeNt, CommentaRies 557,558 n.(b) (13th ed. 1884).

5. As the Court stated in Johnson v. McIntosh, Great Britain has ascertained thorough harsh experience that the Indian nations were "too powerful and brave not to be dreaded as formidable enemies. . . 21 U.S. at 596.

6. The European powers regulated rights of acquisition according to the principle that "discovery gave title to the government by whose subjects, or by whose authority, it was made, against all other European governments, which title might be consummated by possession." However, they did not declare that the Indian nations and tribes were totally without right to their land. 21 U.S. at 573. It was conceded-seemingly by all Europeans-that the Indians were "the rightful occupants of the soil, with a legal as well as just claim to retain possession of it. . . " But the discoverer-nation possessed the power to extinguish that title or to recognize the Indian rights of occupancy. 21 U.S. at 574.

7. 21 U.S. at $574-75$.

8. 21 U.S. at 584-85. See also Tee-Hit-Ton Indians v. United States, 348 U.S. 272, 280 (1955). 
federal governments under which the federal government was delegated the power to regulate commerce and to enter into treaties with the Indians. ${ }^{9}$ Moreover, Congress could control the admission of new states to the Union, ${ }^{10}$ pass laws regarding territories and federal properties, ${ }^{11}$ and insure the supremacy of federal laws. ${ }^{12}$ Despite extravagant claims based on the right of discovery, the federal goverment and its courts recognized, from the earliest years of independence, that the Indians possessed that inherent sovereign power from which stem their treaty rights-rights which the federal government in the exercise of its constitutional control over Indian affairs was bound to honor, but which it frequently violated.

The principle of federal control over new territories was extended to the Louisiana Territory following its purchase from France in $1803 .^{13}$ Although Congress did not for many years enact any laws directly relating to the waters of the Yellowstone River Basin, it was in this period that the Supreme Court, under Chief Justice Marshall, began to lay down principles of treaty interpretation that continue to affect the issue of water rights in the region. Thus, in Worchester \%. Georgia the Court, faced with the issue of the paramount treaty rights of the Cherokee Nation vis-à-vis the laws of Georgia, held that the reference to "hunting grounds" in the Cherokee treaty could not be construed as implying "that any intention existed of restricting the full use of the lands they [the Indians] reserved." 14 The Court thus recognized that the Indians reserved to themselves that which they did not grant to the United States; hence, the particular use to which they put their lands was "a matter of no concern" to the United States. ${ }^{15}$ The Court further rejected the assertion that Indian rights to use reserved lands were limited to the use to which they were put at the time of the treaty. ${ }^{16}$ These early tenets of treaty construction remain extremely important when applied to the present-day reservation of water rights and the uses to which they may be put.

Almost half a century elapsed between the 1803 Louisiana Purchase and the execution of the first Indian treaty pertaining to a portion of the Yellow-

9. U.S. Const. art. I, $\S 8$.

10. U.S. Const. art. IV, \$3.

11. Id. Federal Power Comm n v. Oregon, 349 U.S. 435, 443 (1955); California Oregon Power Co. v. Portland Cement Co., 295 U.S. 142, 162 (1935).

12. U.S. Const. art. VI. This same article asserts that "the Judges in every State shall be bound [by the Constitution of the United States, its laws and its treaties] anything in the Constitution or Laws of any State to the Contrary notwithstanding."

13. Treaty of Paris, Act of March 26, 1804, ch. 38. \$ 15, 2 Stat. 283.

14. Worchester v. Georgia, 3l U.S. (6 Pel.) 515, 553 (1832). One year earlier, in Cherokee Nation v. Georgia, Marshall first declared that the Indians were best denominated as "domestic dependent nations" bound to the federal government by a trust relationship resembling " that of a ward to his guardian." 30 U.S. (5 Pet.) 1, 17 (1831).

15. 31 U.S. at 553.

16. As the Court in Worchester pointed out, the use of the phrase "hunting grounds" in early treaties with the Crown did not imply "a right in the British government to take their lands, or to interfere with their internal government." Id. 
stone River Basin. The Treaty of Fort Laramie, entered into on September 17, 1851, recognized the rights of the Cheyenne and Arapahoe to a broad stretch of land that includes part of the coal fields here under consideration. ${ }^{17}$ A few years later, on May 30, 1854, Congress adopted "An Act to Organize the Territories of Nebraska and Kansas," which covered an area embracing the present states of Montana and Wyoming and including, of course, the Yellowstone River and all its tributaries. ${ }^{18}$ Congress guaranteed that nothing in the Act would "impair the right of person or property now pertaining to the Indians in said Territory, so long as such rights shall remain unextinguished by treaty between the United States and such Indians." Moreover, the Indians would not have their lands included in the territory of Nebraska without their consent. The United States remained fully empowered to exercise its authority "respecting such Indians, their lands, property, or other rights, by treaty, law, or otherwise." 19

The Territorial Act did not refer directly to any controlling law of water rights. It was in the gold fields of California and in subsequent judicial and legislative action that water laws were formulated. At the time Mexico ceded California to the United States under the 1848 Treaty of Guadalupe Hidalgo ${ }^{20}$ there was neither federal nor state law applicable to rights to the use of water on the vast public domain which had been acquired. To achieve order in the gold fields the miners developed their own customs, usages, and regulations, and these were to form the basis for all of western water law. In its simplest terms, these customs declared that the individual who first made use of an available water supply had a prior right over all other claimants to as much of the water as he could beneficially use. Moreover, the first user could appropriate to his own use all of the waters of a stream if he could apply it to beneficial uses. ${ }^{21}$ The California legislature gave legal effect to these customs in $1851 .{ }^{22}$ Thereafter, further support for this developing doc-

17. The Treaty provides that the territory of the Cheyenne and Arapahos would embrace an area commencing at a point on the north fork of the Platte River

thence up the north fork of the Platte River to its source; thence along the main range of the Rocky Mountains to the head-waters of the Arkansas River; thence down the Arkansas River to the crossing of the Santa Fe road; thence in a northwesterly direction to the forks of the Platte River; and thence up the Platte River to the place of beginning.

11 Stat. 749 (1855); 2 C. Kappler, Indian Affairs-Laws and Treaties 595 (1904). Moreover, by the terms of the Treaty the nations and tribes involved did not "abandon or prejudice any rights or claims they may have to other lands..."Id. The Treaty of October 17, 1855 with the Blackfoot Indians also takes cognizance of the provisions of the Treaty of Fort Laramie. 11 Stat. 657 ; C. KAPPLER, supra at 736.

18. Ch. 59, 10 Stat. 277. See also C. Paullin, Atlas of the Historical Geography of the UNited STATES plate 64 (1932).

19. Ch. 59, 10 Stat. $277,278$.

20. Act of Feb. 2, 1848, 9 Stat. 922.

21. See Jennison v. Kirk, 98 U.S. 453, 457-58 (1879).

22. California Practice Act, Cal. Stat. ch. 5, $\S 249$ (1851). See also Irwin v. Phillips, 5 Cal. $140,146-47$ (1855). 
trine of prior appropriation was supplied by the federal government and by the territorial legislature. ${ }^{23}$

In 1866 Congress passed its first law affecting rights to the use of water on public lands, including those in the territory of Montana. The Act declared "[t]hat whenever, by priority of possession, rights to the use of water for mining, agricultural, manufacturing, or other purposes have vested and accrued, and the same are recognized and acknowledged by the local customs, laws, and the decisions of courts, the possessors and owners of such vested rights shall be maintained and protected in the same."24 Later, in an attempt to attract settlers to the arid lands of the West, Congress passed the Desert Land Act of 1877 which authorized the appropriation of "surplus" water on the nation's public lands by those who demonstrated actual appropriation and use of such waters pursuant to state or territorial laws. ${ }^{25}$ With reference to the Acts of 1866 and 1877 , it is, however, important to note that during this period the federal government continued to accord full legal effect to treaties with the Indian tribes, ${ }^{26}$ and to pass laws for the organization of new territories that acknowledged "the rights of persons or property now pertaining to the Indians." 27 Moreover, the courts construed and applied the term "public lands" as used by Congress to mean only those lands "unqualifiedly subject to sale and disposition" 28 by the federal government, a characterization

23. See Lux v. Haggin, 69 Cal. 255, 10 P. 674, 721 (1886).

24. Act of July 26,1866 , ch. 262, $\$ 9,14$ Stat. 251, 253 (codified in 43 U.S.C. $\$ 661$ (1970)). See also Act of July 9, 1870, ch. 237, $\$ 17,16$ Stat. 217,218 (codified in 43 U.S.C. $\S 661$ (1970)), which provides that, by the Act of 1866 , "all patents granted, or preemption or homesteads allowed, shall be subject to any vested and accrued water rights, or right to ditches and reservoirs used in connection with such water rights, as may have been acquired under or recognized."

25. Ch. $107, \S 1,19$ Stat. 377 (codified in part in 43 U.S.C. $\$ 321$ (1970)) states that one claiming water for the desert land entry must "depend upon bona fide prior appropriation: and such right shall not exceed the amount of water actually appropriated, and necessarily used for the purpose of irrigation and reclamation...."

26. See, e.g., Treaty With the Crow Tribe, May 7, 1868, 16 Stat. 649, which, in the words of the Supreme Court, created a large reservation in the territory of Montana for the ". 'absolute and undisturbed use and occupation' of the Crow Indians, and they undertook to make thier permanent homes thereon." United States v. Powers, 305 U.S. 527, 528 (1939). See also Treaty With the Shoshonees and Bannocks, July 3, 1868, 15 Stat. 673, establishing the Wind River Indian Reservation in the Territory of Wyoming.

27. The Act of July 25, 1868, ch. 235, 15 Stat. 178 (reprinted in l WYo. STAT. $\$ 35$ (1957)). This Organic Act established a temporary government for the territory of Wyoming. The Montana Territorial Act gave additional safeguards to the Indians by guaranteeing that the treaties, laws, and other engagements made by the United States with the Indians "inhabitating the territory embraced within the provisions of this act, shall be faithfully and ridgidly observed, anything contained in this act to the contrary notwithstanding. .." Act of May 26, 1864, ch. 95, $\$ 17,13$ Stat. 85, 91 (reprinted in 1 MoNr. Rev. CoDE $\$ 17$ (1947)).

28. Federal Power Comm'n v. Oregon, 349 U.S. 435, 448 (1955). It was provided in the Desert Land Act of 1877 that "all surplus water over and above such actual appropriation and use, together with the water of all lakes, rivers and other sources of water supply upon the public lands and not navigable, shall remain and be held free for the appropriation and use of the public for irrigation, mining and manufacturing purposes subject to existing rights." $\mathrm{Ch} .107, \S 1,19$ Stat. 377 (codified in part in 43 U.S.C. $\$ 321$ (1970)) (emphasis added). 
which is inapplicable to lands of Indians or Indian tribes. ${ }^{29}$ Only surplus waters on federal lands properly designated as "public lands" were open to appropriation under federal law.

As the territories of Montana and Wyoming approached statehood it was clear that water would become the basis-and the limit-of their future growth. Both territories therefore moved to assert greater control over the water resources within their boundaries and to regularize the laws governing its appropriation. Montana's Territorial Legislative Assembly enacted a primitive water code in 1865 that provided for the distribution of water "in a just and equitable proportion."30 The territories' highest court thereafter held that with regard to the apportionment of water, "equity declares that he who is first in time is first in right," 31 and the Territorial Legislature gave formal recognition to this principle in $1885 .^{32}$ The Montana statutes and cases did not, in this early period, explicitly reject the common law doctrine of riparian rights. That doctrine recognizes the principle that the owners of lands which abut upon natural streams or bodies of water have vested rights in those waters. The doctrine of riparian rights denies a landowner whose property does not abut upon a stream any right to water, irrespective of need or purpose. By contrast, the doctrine of prior appropriation authorizes the diversion and use of water to non-adjacent lands. Moreover, it assures a senior and better right to the appropriator based upon his date of priority. Beneficial use, therefore, is the basis, the measure, and the limit of the rights of the appropriator, with the first in time being the first in right. It was not until 1921 that the Supreme Court of Montana firmly rejected the common law rule of riparian rights in favor of the doctrine of prior appropriation. ${ }^{33}$

Where Montana was slow to formulate its laws respecting rights to the use of water or to establish centralized control over the administration and appropriations of rights, Wyoming reached the same goals more quickly and directly. From its inception, the territory of Wyoming declared its adherence to the doctrine of prior appropriation ${ }^{34}$ and formulated administrative procedures to implement that doctrine. ${ }^{35}$. The Wyoming Territorial Legislative As-

29. United States v. Minnesota, 270 U.S. 181, 206 (1926).

30. An Act to Protect and Regulate the Irrigation of Land in Montana Territory, [1864] Laws of Mont. Territory 367.

31. Thorpe v. Woolman, 1 Mont. 168, 171-72 (1870).

32. Mont, Compiled Stat. ch. 74, \$1254 (1887).

33. Mettler v. Ames Realty Co., 61 Mont. 152, 201 P. 702 (1921).

34. Act to Create and Regulate Corporations, ch. 8, \$§ 28, 29 [1869] Wyo. Laws 234, 244-45. See also Act to Develop Mining Resources in the Territory, ch. 22, §§ 15-18 [1869] Wyo. Laws 307, 310-11.

35. Act to Protect and Legislate the Irrigation of Lands in the Territory of Wyoming, Wyo. Compiled LAws ch. $65, \S 1$ (1876). A later territorial statute referred to this Act as the "[r]ights of riparian owners." Wyo. Rev. Stat. tit. 19, \$1317 (1887)). However, when a claimant sought to assert rights as a riparian owner, the Wyoming court was quick to declare: "The common-law 
sembly went further, stating that: "The water of every natural stream not heretofore appropriated within this Territory, is hereby declared to be the property of the public, and the same is dedicated to the use of the people, subject to appropriation as herein provided."36 Montana made a similar claim in earlier statutes and has updated its practices and procedures respecting the acquisition, control, and use of the state's water resources through its revised constitutions and statutes. ${ }^{37}$

At the time of their admission to the Union, both Montana and Wyoming acknowledged existing Indian rights and the plenary power of Congress to control Indian affairs. The Enabling Act of 1889 that authorized statehood for Montana (as well as North Dakota, South Dakota, and Washington) provided: "That the people inhabiting said proposed States do agree and declare that they forever disclaim all right and title . . . to all lands lying within said limits owned or held by any Indian or Indian Tribes." 38 This disclaimer was repeated in the various western state constitutions, ${ }^{39}$ including that of Wyoming. ${ }^{40}$

In both Montana and Wyoming, therefore, the law of water rights has reached essentially the same results. The right to the use of water is regarded as a usufructory right, ${ }^{41}$ a vested right to the corpus of water flowing in a natural stream. ${ }^{42}$ This right to the use of water is an interest in real property and entitled to all the dignity of a freehold interest. The date of priority is in

doctrine relating to the rights of a riparian proprietor in the water of a natural stream, and the use thereof is unsuited to our requirements and necessities, and never obtained in wyoming." Moyer v. Preston, 6 Wyo. 308, 318, 71 Am. St. R. 914, 919 (1896).

36. Act to Regulate the Use of Water for Irrigation, ch. 61, § 14 [1869] Wyo. Laws 294, 299.

37. Mont. Const. art. III, § 15 (1889). See generally 2A P. Nichol, EMinent Domain $\$ 7.621$, at 626 (1975); Annot., 27 A.L.R. 519 (1923); Annot., 9 A.L.R. 583 (1920). A similar claim was made in Wyoming's constitution. "The waters of all natural streams, springs or lakes or other collections of still water, within the boundaries of the state, are hereby declared to be the property of the state." Wyo. Const. art. $8, \S 1$. Whereas Wyoming exercised its full power and authority over the waters within its jurisdiction at the time it was admitted to the Union, Montana did not take strict control of the acquisition, administration, and adjudication of rights to the use of water until 1972. Mont. Const. art. 10, 33 (1972).

38. Act of Feb. 22, 1889, ch. 180, $\$ 4,25$ Stat. 676, 677.

39. Monr. Const. ord. 1 (1889); Mont. Const. art. 1 (1972).

40. Wyo. Const. art. $21, \S 26$.

41. See Lindsey v. McClure, 136 F.2d 65, 70 (10th Cir. 1943); Wright v. Best, 19 Cal. 2d 368, 121 P.2d 702 (1942); Fuller v. Swan River Placer Mining Co., 12 Colo. 12, 19 P. 836 (1888); Sowards v. Meagher, 37 Utah 212, 108 P. 1112 (1910).

42. This right is subject to extensive state regulation. See, e.g., Wyo. Stat. $\$ 41-201$ (1957). See generally 2 S. Wiel, Water Rights in the Western States \$ 1184 (3d ed. 1911); see R. Clark, WATERS AND WATER Rights (1967). Failure to comply with a state regulatory scheme would not necessarily serve to divest one who had actually diverted waters prior to a claimant who did conform to the statutory scheme. See Murray v. Tingley, 20 Mont. 260, 50 P. 723, 724-25 (1897). The overriding importance of the doctrine of prior appropriation was stressed in Morris v. Bean, 146 F. 423 (9th Cir. 1906), aff'd, 221 U.S. 485 (1911), in which Justice Holmes, writing for the Court, also noted that the doctrine of prior appropriation obtained in Montana and Wyoming even prior to their organization as territories. 
itself a valuable property, a component of that real property interest. ${ }^{43}$ When courts adjudicate rights to the use of water, the suits are in the nature of a proceeding to quiet title to real property. Courts do not create the rights by adjudicating them; they merely accord to them judicial cognizance. ${ }^{44}$ States, in the exercise of their police power, have adopted elaborate procedures for the acquisition, administration, and adjudication of rights to the use of water. Wyoming has pioneered the way for many western states in establishing strict regulation under a board of control created by statute pursuant to its constitution. ${ }^{45}$ However, such policy regulations pertain only to matters coming within the scope of state jurisdiction. They have no application to federal rights or to the rights of Indian tribes and people.

\section{II}

\section{The Clash of Federal and State. Water Rights}

The conflict between the states and the federal government over water rights involves two basic questions. First, has the federal government conveyed or delegated to the states the power to regulate the use of water on federal and Indian lands by virtue of statutes permitting appropriations according to state laws on "public lands"? And second, absent a specific delegation, to what extent may the states nevertheless exercise regulatory control over the waters that pass through lands that lie within their jurisdictions?

Despite the claims of Wyoming and Montana to all the unappropriated waters within their territories, the courts have recognized that under the

43. It is elementary that rights to the use of water are interests in real property. $2 \mathrm{~S}$. WIEL, supra note 42, at 20, 21,301 . See Ashwander v. T.V.A., 297 U.S. 288, 330 (1936); United States v. Chandler-Dunbar Co., 229 U.S. 53, 73 (1913). A priority to use water out of a stream is itself a component of the interest in real property.

Property rights in water consist not alone in the amount of the appropriation, but also in the priority of the appropriation. It often happens that the chief value of an appropriation consists in its priority over other appropriations from the same natural stream.

Hence, to deprive a person of his priority is to deprive him of a most valuable property right . . . .

Nichols v. McIntosh, 19 Colo. 22, 34 P. 278, 280 (1893) (emphasis added). See also Whitmore v. Murray City, 107 Utah 445, 154 P.2d 748, 75 l (1944). No person may be deprived of this interest without due process of law. Nichols v. McIntosh, supra at 278; see United States v. Gerlach Livestock Co., 339 U.S. 725 (1950).

44. Proceedings to adjudicate water rights are generally equated with proceedings to quiet title to realty. Rickey Land \& Cattle Co. v. Miller \& Lux, 152 F. 11, 15 (9th Cir. 1907). aff d. 218 U.S. 258 (1910); United States v. Ahtanum Irrigation Dist., 236 F.2d 321, 339 (9th Cir. 1956); Crippen v. XY Irrigation Co., 32 Colo. 447, 76 P. 794 (1904); Louden v. Handy Ditch Co., 22 Colo. 102, 43 P. 535 (1895). See also C. Kinney, Irrigation and Water Rights $\S 1569$, at 2844 (2d ed. 1912).

45. Wyo. Stat. § 41-154 (1957); Wyo. Const, art. 1, §31. See also Mont. Const. art 9, § 3. The Wyoming constitution declared that, although private property shall not be taken by eminent domain for private use, an exception would exist for private ways of necessity and for "reservoirs. drains, flumes or ditches on or across the lands of others for agricultural, mining, milling, domestic or sanitary purposes ... ."Wyo. Const. \& 32. Provision, of course, was made for just compensation for property taken under proviso. 
Property and Commerce Clauses of the Federal Constitution, Congress retains control over the public domain and navigable waters, and that within this sphere the power of the federal government is supreme. It was pursuant to these powers that with the acquisition of the Louisiana Purchase there passed to the nation, subject to the rights of the Indians, title to "all lands, lakes [and] rivers" 46 in the territory. Hence, the statutory claims of Wyoming, Montana, and other states to all the unappropriated waters within their territories have been held not to vest "in the state title or ownership of the water as a proprietor." 47 Rather, as the Wyoming ${ }^{48}$ and Colorado ${ }^{49}$ courts have noted, these state statutes are an exercise of regulatory authority, not an exercise of proprietary rights. Moreover the United States Supreme Court has held that these regulatory powers are further circumscribed as they relate to federal title in the public domain. Pursuant to its constitiutional authority, said the Court, "the government possessed the power to dispose of land and water thereon together, or to dispose of them separately." 1866, 1870, and the Desert Land Act of 1877,51 the federal government opened to appropriation and use of the public surplus waters on the public lands. The Court found that by this action Congress had vested in the states the power to affect the water rights of persons who took public lands by patent from the United States. Thus by action of these statutes a patent to "public land" did not carry with it rights to the use of water, as Congress had provided that those rights could only be separately acquired by compliance with "the customs, laws, and judicial decisions of the state of their location." 52 When the United States withdrew "public lands" and reserved them for federal purposes, the then existing surplus waters were no longer open to appropriation pursuant to state laws. Since the federal government is the source of the full title, it has the power to reserve the surplus waters for its own needs and those of Indians. ${ }^{53}$

Moreover, as the Supreme Court stated in Federal Power Commission \%.

46. E. Vattel, Law of Nations 120 (1883). Full import of the legal aspects of the investiture of complete title in the United States is reviewed at length by the Supreme Court in United States v. California, 332 U.S. 19 (1947).

47. Wrathall v. Johnson, 86 Utah 50, 40 P.2d 755, 777 (1935). This case, decided by the Utah Supreme Court, construed language in its own statutes virtually identical to the Montana and Wyoming laws.

48. Farm Investment Co. v. Carpenter, 9 Wyo. 110, 61 P. 258, 260 (1900).

49. Farmers' Independent Ditch Co. v. Agricultural Ditch Co., 22 Colo. 513, 45 P. 444, 449

(1896). Farmers' High Line Canal Co. v. Southworth, 13 Colo. 111, 21 P. 1028, 1031 (1889).

50. California Oregon Power Co. v. Beaver Portland Cement Co., 295 U.S. 142, 162 (1935).

51. See references at notes 24 and 25 supra.

52. California Oregon Power Co. v. Beaver Portland Cement Co., 295 U.S. at 162.

53. Howell v. Johnson, 89 F. 556 (9th Cir. 1898). The separation of the rights to the use of surplus waters from the "public lands" for the purpose of disposal by the states was applicable only to lands designated in the statutes and did not pertain to Indian lands. United States v. Minnesota, 270 U.S. 181 (1926). 
Oregon, under the Acts of 1866, 1870, and the Desert Land Act of 1877, the state does not have the right to exercise its regulatory powers when a license has been granted by a federal agency for the construction of a dam on the reserved lands of the federal government or an Indian tribe, although the waters are within the state's jurisdiction. In overruling the court of appeals, the Supreme Court stated: "To allow Oregon to veto such use, by requiring the State's additional permission, would result in the very duplication of regulatory control precluded by the First Iowa decision. No such duplication is called for by the [Federal Power Commission Act]." 54 The Court in First Iowa relied on the Commerce Clause to deny state regulatory control of a navigable stream, ${ }^{55}$ and in Federal Power Commission used the Property Clause to deny comparable power over public lands and reservations. ${ }^{56}$ Similar rulings have been handed down in cases involving reclamation projects ${ }^{57}$ and reservations created by executive order. ${ }^{58}$ Indeed, it is recognized that where federal or Indian lands or rights to the use of water are involved, the power of Congress is absolute, ${ }^{59}$ and states may not limit the exercise of that power vested in agents or agencies of the federal government. ${ }^{60}$

Another of the constitutional powers that directly affects control over water rights between the state and federal governments is the Compact Clause of article I. It declares, in part, that "[n]o state shall, without the Consent of Congress . . . enter into any Agreement or Compact with another State ...." ${ }^{\prime \prime 1}$ As the Supreme Court has noted, "the prohibition is directed to the formation of any combination tending to the increase of political power in the States, which may encroach upon or interfere with the just supremacy of the United States." 62 Thus, the Yellowstone River Compact of 1950 formed among the states of Montana, Wyoming, and North Dakota specifically provides that the sovereignty and jurisdiction of the federal government, ${ }^{63}$ as well as the water rights of the Indian tribes, ${ }^{64}$ shall not be affected by the Compact. The agreement, therefore, could not constitutionally restrict or change the responsibilities or powers of the United States or the Indians within the drainage system to which the Compact pertains. ${ }^{65}$

54. Federal Power Comm'n v. Oregon, 349 U.S. 435, 445 (1955).

55. First Iowa Hydro-Electric Coop. v. Federal Power Comm'n, 328 U.S. 152 (1945).

56. 349 U.S. at $442-43$.

57. Ivanhoe Irrigation Dist. v. McCracken, 357 U.S. 275 (1958).

58. Arizona v. California, 373 U.S. 546 (1963).

59. United States v. San Francisco, 310 U.S. 16, 29, 30 (1940).

60. Arizona v. California, 373 U.S. at 590.

61. U.S. Const. art. I, $\$ 10$.

62. Virginia v. Tennessee, 148 U.S. 503, 519 (1893).

63. 6 Mont. Rev. Code $\$$ 89-903, art. XVI (1947); 12 N.D. Cent. Code $\S 61-23-01$, art. XII (1960); 9 WYo. STAT, 41-517, art. XVI (1957).

64. 6 Mont. Rev. Code $\S 89-903$, art. VI (1947); 12 N.D. Cent. Code $\S$ 63-23-01, art. VI (1960); 9 Wro. Srat. \$ 41-511, art. VI (1957).

65. Pennsylvania v. Wheeling \& Belmont Bridge Co., 59 U.S. 421,433 (1855). 
There is, then, an unbroken line of authority which holds that the federal government is exempt in its own jurisdiction from state regulatory controls. As Chief Justice Marshall said in McCulloch \%. Maryland: "If any one proposition could command the universal assent of mankind, we might expect it would be this-that the government of the Union, though limited in its powers, is supreme within its sphere of action." 66 In denying that a state could tax a federal agency, Marshall emphasized that the "power of taxing" the agency "may be exercised so as to destroy it." 67 Similarly, if states had the power to veto this nation's will respecting its rights to the use of water, that authority would be tantamount to vesting in those subordinate quasi-sovereigns the power to destroy it, particularly in the arid and semi-arid West. This language from $M c$ Culloch $v$. Maryland leaves no doubt as to where the power resides when national interests are involved in the development of the water resources of the Yellowstone River Basin: "No trace is to be found in the constitution, of an intention to create a dependence of the government of the Union on those of the States, for the execution of the great powers assigned to it. Its means are adequate to its ends; and on those means alone was it expected to rely for the accomplishment of its ends." 68

To allow the states of Montana or Wyoming to regulate the actions of the federal government would force the government to resort "to means which it cannot control," thus rendering "its course precarious" and its powers dependent "on other governments, which might disappoint its most important designs." Such control by the states of the nation "is incompatible with the language of the Constitution." 69 It should be emphasized, nevertheless, that where rights to the use of water have been privately acquired by compliance with the laws of the states of Montana and Wyoming they may only be taken by the federal government through the exercise of its powers of eminent domain.

\section{III}

The Nature and Extent of Indian Water Rights

Although the federal government may assert against the states its control over waters on the public domain and Indian reservations, the rights of the federal government and the Indian tribes are distinct and separate. Whereas federal water rights became vested in it by purchase or conquest and the control of those rights stems from powers granted by the Constitution, Indian water rights are vested in the Indian tribes from time immemorial. These

66. 17 U.S. (4 Wheat.) 315,404 (1819).

67. 17 U.S. at 427.

68. 17 U.S. at 424.

69. Id. State courts may, however, exercise jurisdiction over federal water rights, including Indian water rights held in trust by the federal government, when so authorized by Congress. Colorado River Water Conservation Dist. v. United States, 96 S. Ct. 1236 (1976). 
Indian rights were reserved by the tribes through the treaties signed with the federal government. The courts have drawn a clear distinction between United States and Indian water rights and have given close consideration to the scope of Indian rights. Moreover, the courts have recognized the obligation of the United States, as trustee of the Indian tribes and people, to preserve and protect the Indian rights to the use of water.

The leading case on Indian water rights is Winters $\%$ United States. ${ }^{70}$ The United States, on behalf of Montana's Fort Belknap Tribe, sought to enjoin Winters and others from diverting water from the Milk River at a point above the reservation's northern boundary. The Supreme Court was asked to determine the effect of the Treaty of $1855^{71}$ and of a subsequent agreement entered into between the national government and the tribe, neither of which made mention of water. In affirming the final decree enjoining the defendants, the Supreme Court held that when the Fort Belknap Indians ceded to the United States their vast domain they "had command of the lands and the waters-command of all beneficial use" whether for hunting, grazing livestock, "or agriculture and the arts of civilization." [retained by the Indians] were arid and, without irrigation, were practically valueless," the Court then asked: "Did they give up all this? Did they reduce the area of their occupation and give up the waters which made it valuable or adequate?"73 Indicating its scepticism of affirmative answers to these questions and reiterating the accepted rule that ambiguous treaty provisions should be resolved from the standpoint of the Indians, the Court then held that "the Government is asserting the rights of the Indians." 74 This holding was consonant with the Court's decision one year earlier in a fishing rights case, in which the Court held that the treaty with the Yakima Indians "was not a grant of rights to the Indians, but a grant of rights from them-a reservation of those not granted."75 This right, said the Court at that time, "was intended to be continuing against the United States and its grantees as well as against the State and its grantees."76 In subsequent years the courts have consistently upheld and applied the Winters reserved rights doctrine, the Supreme Court having specifically implemented it to define the rights of the Crow Indians to

70. 143 F. 740,749 (9th Cir. 1906).

71. Treaty With the Blackfoot Indians, Oct. 17, 1855, 11 Stat. 657. The court was also called on to consider the effect of an Act of April 15, 1874, ch. 96, 18 Stat. 28, which reduced the size of the reservation, and of the Act of May 1, 1888, which established its present boundaries. Ch. 213, 25 Stat. 113.

72. Winters v. United States, 207 U.S. 564, 575 (1908).

73. 207 U.S. at 575.

74. Id. The Court also rejected the argument that the admission of Montana to the union in 1889 abrogated the federal government's convenant with the Fork Belknap Indians. 207 U.S. at 577.

75. United States v. Winans, 198 U.S. 371,381 (1939).

76. 198 U.S. at $381-82$. 
the waters of the Big Horn River, a major tributary of the Yellowstone River. ${ }^{77}$

In 1908, the same year that the Supreme Court rendered the hallmark decision in Winters, the Court of Appeals for the Ninth Circuit, in Conrad Investment Company v. United States, placed other users on notice that the Indians retained for themselves "whatever water . . . may be reasonably necessary, not only for present uses, but for future requirements."78 Conrad and subsequent cases have, therefore, consistently presented a caveat to all users of water in which Indians have a valid legal interest. Moreover, the Supreme Court has recognized that Winters rights are equally applicable to reservations that were created not by treaty but by executive order. Although earlier courts in reported cases had considered only Indian rights involving treaty reservations, a 1939 court of appeals decision attempted to limit Indian water rights on an executive order reservation to historic uses. ${ }^{79}$ The Supreme Court, however, in Arizona \%. California, without distinguishing between executive order and treaty reservations, held that the federal government could and did reserve rights to the use of water to meet present and future water requirements for Indians who were placed on executive order reservations. ${ }^{80}$

The Arizona $\%$. California Court also rejected the argument that reservation needs should be fixed according to a population projection. Instead, the Court stated: "[T]he only feasible and fair way by which reserved water for the reservations can be measured is irrigable acreage." 81 There is, however, no reason in law, logic, or equity to limit Indian rights to agriculture. Although agricultural uses predominate in the Colorado River Basin, to which the Court addressed itself in Arizona, in the coal fields of the Yellowstone River Basin industrial uses may ultimately be foremost. Earlier courts recognized the validity of multiple purpose use $^{\mathbf{8 2}}$ and it has more recently been held that Indian rights to water may be exercised for any beneficial use. ${ }^{83}$

It will be recalled, too, that in Winters the Court recognized that the Indians, prior to the advent of the white man, had control of their lands and waters for beneficial use. In Winters, the court also recognized that on the reservations the Indians could turn both "to agriculture and the arts of civilization." ${ }^{84}$ Surely this includes industrial as well as irrigation rights. Yet, it

77. United States v. Powers, 305 U.S. 527 (1939).

78. 161 F. 829, 832 (9th Cir. 1908). To underscore the measure of the rights thus reserved by the Indians, the court of appeals declared that its ruling recognized the Indian rights for future requirements and "is clearly within the terms of the treaties as construed by the Supreme Court in the Winters case." Id. (emphasis added).

79. United States v. Walker River Irrigation Dist., 104 F.2d 334, 340 (9th Cir. 1939).

80. 373 U.S. 546 (1963).

81. 373 U.S. at 601 .

82. United States v. Walker River Irrigation Dist., 104 F.2d at 340 .

83. United States v. Ahtanum Irrigation Dist., 330 F.2d 897, 915 (9th Cir. 1964).

84. 207 U.S. at 576. 
is precisely this issue (and the desperate efforts of the Reclamation bureau to denegrate Indian rights) which divides the Department of the Interior at the present time. The Bureau of Reclamation espouses the argument of the industrial giants, asserting that Indian reserved water rights are limited to agricultural purposes. If this view prevails it would free water for use by coal interests. Furthermore, it would violate one of the basic principles of property law, as stated by Wiel, ${ }^{85}$ namely, that rights to the use of water, being property rights, may be enjoyed and utilized for any purpose, so long as the rights of others are not impaired.

In addition to arguing that Indian reserved water rights are limited by the purposes to which they may be placed, state governments-and some federal agencies-have urged other restrictions on Indian water rights. They would, for example, limit Indian rights to waters within or bordering their reservations. The courts have consistently rejected any argument that states may authorize a user to divert waters from the tributary sources of rivers in which there are vested rights that would be impaired by such diversions. ${ }^{86}$ As the Oregon Supreme Court stated: "The rights of prior appropriators from a stream cannot be impaired by subsequent appropriations of water from its tributaries." 87 These concepts have also been applied to Indian rights. Moreover, the courts have rejected the argument that failure on the part of the federal government to assert Indian water rights means that these rights have been forfeited. ${ }^{88}$ There are, of course, many instances in which Indians were using water on their lands prior to white settlement. ${ }^{89}$ Unfortunately, however, in many cases the interagency disputes ${ }^{90}$ have delayed Indian water developments. That delay, however, in the eyes of the law, does not justify a

85. I S. WIEL, supra note $42 \S 496$, at 529 .

86. See Nebraska v. Wyoming, 325 U.S. 589, 618 (1945); Wyoming v. Colorado, 259 U.S. 419 (1921); Bean v. Morris, 221 U.S. 485 (1911); United States v. Ahtanum Irrigation Dist., 236 F.2d 321,340 (9th Cir. 1956); Strickler v. Colorado Springs, 16 Colo. 61, 26 P. 313, 315 (1891); Richlands Irrigation Co. v. Westview Irrigation Co., 96 Utah 403, 80 P.2d 458, 465 (1938).

87. Dry Gulch Ditch Co. v. Hutton, 170 Ore. 656, 133 P.2d 601, 611 (1943). See also Richland Irrigation Co. v. Westview Irrigation Co., $96 \mathrm{Utah}$ at 403,80 P.2d at 465.

88. United States v. Ahtanum Irrigation Dist., 236 F.2d 32 I, 328 (9th Cir. 1956), cert. denied, 352 U.S. 988 (1957).

89. The first venture in irrigation construction in the United States was the authorization by Congress in 1867 for the construction of a project on the Colorado River Indian Reservation. Act of March 2, 1867, ch. 173, 14 Stat. 492; see F. Cohen, Handbook on Federal Indian Law 248 (1942): Arizona v. California, 373 U.S. at 598-601. The Indian General Allotment Act of 1887, ch. 119, 24 Stat. 388 (codified in scattered sections of 25 U.S.C. (1970)), also provided for irrigation projects and the distribution of water among the "Indians residing" on the reservations. 25 U.S.C. $\$ 381$ (1970). In 1885, prior to the admission of Wyoming and Montana to the union, Congress appropriated money for irrigation on the Crow Reservation. United States v. Powers, 305 U.S. 527, 531 (1939). It has also been held that Congress, under the Reclamation Act of 1902 , ch. 1039, 32 Stat. 388 (codified in scattered sections of 43 U.S.C. (1970)), did not give up to the states its power to regulate the waters granted or to limit delivery of water to 160 acres in a single ownership. Nebraska v. Wyoming, 325 U.S. 589, 615 (1945); Ivanhoe Irrigation Dist. v. McCracken, 357 U.S. 275,292 (1958).

90. See 2 Joint Economic Comm., Federal Encroachment on Indian Water Rights and 
loss of Indian reserved rights. A far more serious question is rapidly emerging. The power of the federal government to apply reserved water rights on lands held in trust by the federal government for the development of national energy resources cannot be seriously questioned. What may be questioned is whether federal officials will act to protect Indian rights and to assist Indians in the exercise of those rights even as they try to implement a national energy program.

IV

Federal Resource Programs and Indian Water Rights

The present concern with developing additional energy resources for the nation has focused renewed attention on the distribution of waters in the Yellowstone River Basin. Drastic changes were, however, transpiring in regard to national and state policies in this area well in advance of the present crisis. In particular, significant alterations were occurring in the water marketing programs of the federal agencies. Careful consideration of the legality of these programs is essential to a determination of water rights within the Yellowstone system.

Beginning in 1967 the Bureau of Reclamation initiated a program for the sale to industrial users of waters from the Big Horn River. Contracts were signed which purported to effectuate the sale of approximately 625,000 acrefeet of the water from the Big Horn River and the streams impounded in Big Horn Lake, a reservoir created by the Yellowtail Dam on the Crow Indian Reservation of Montana. Two years later, a contract with Sun Oil Company purported to provide 35,000 acre-feet of Big Horn River water from the Boysen Reservoir, located on the Wind River Indian Reservation in Wyoming. (The Wind River, a major tributary of the Big Horn, rises on the Wind River Reservation.) About two-thirds of the total amount contracted for would be used by the major oil companies for the development of coal resources in Wyoming.

Authority for these contracts was sought in the Federal Reclamation Act of $1902^{91}$ and in the Yellowstone River Compact.92 These laws, however, deal with agricultural uses and acknowledge the rights of prior appropriators. Recognizing that reclamation projects were in furtherance of agricultural development, Congress provided in the Act of February 25, $1920^{93}$ that the sale of water by the Bureau of Reclamation for purposes other than irrigation is conditioned on a showing that no other practicable source of water exists for

\footnotetext{
The IMPairment of Reservation Development, in TOWard Economic Development for Native American Communities, 9 lst Cong., 1st Sess. 460 (1970).

91. Ch. 1093, 32 Stat. 388.

92. See references at notes 62 and 63 supra.

93. 43 U.S.C. $\$ 521(1970)$.
} 
the proposed project, that such use would not adversely affect irrigation projects, and that "no water shall be furnished" for non-agricultural purposes if it is detrimental "to the rights of any prior appropriator." 94 Moreover, the sale of project water could not be made without the consent of the water users associations that usually administer the projects.

The 1920 Act must be read in the light of subsequent legislation envisioning the multiple use of water in the entire Missouri River Basin, of which the Yellowstone and Big Horn Rivers form a part. The Reclamation Project Act of $1939^{45}$ authorized the sale of water from reclamation projects for municipal or miscellaneous purposes. Although the requirement for approval by the water users on the project was omitted, that power survived under the earlier acts. The 1939 Act vested in the Secretary of the Interior broad discretionary power to dispose of water from irrigation projects so long as it did not impair the efficiency of those projects. Moreover, the Secretary's powers obviously could not transcend the constitutional rights of users to be free from the seizure of vested rights without due process of law and the payment of just compensation.

Another fundamental act pertaining to the waters of the Yellowstone River Basin is the Flood Control Act of $1944 .{ }^{96}$ It combines the powers of the Bureau of Reclamation and the Corps of Engineers by authorizing the Secretary of the Army, as chief administrator of the Corps of Engineers, "to make contracts with States, municipalities, private concerns, or individuals . . for domestic and industrial uses for surplus water that may be available at any reservoir under the control of the Department of the Army." "97 That authority, however, is subject to the condition that "no contracts for such water shall adversely affect then existing lawful uses of such water." 98 In the Water Supply Act of 1958 Congress further authorized the Corps of Engineers or the Bureau of Reclamation to "impound water for present or anticipated future demand or need for municipal or industrial water." 99

These statutes, however, leave crucial issues unresolved. They do not propose to authorize the seizure of Indian water rights pursuant to the national power of eminent domain. There is no suggestion in any of the acts that the rights of the Indians would be subject to infringement by those broad statutory schemes in the Reclamation Laws. Despite the multiple use provisions, it is, therefore, doubtful whether these statutes empower the Bureau of Reclamation to sell water from the Big Horn River and its tributaries in contravention of treaties or any other rights of the Indian tribes. Clearly the trust re-

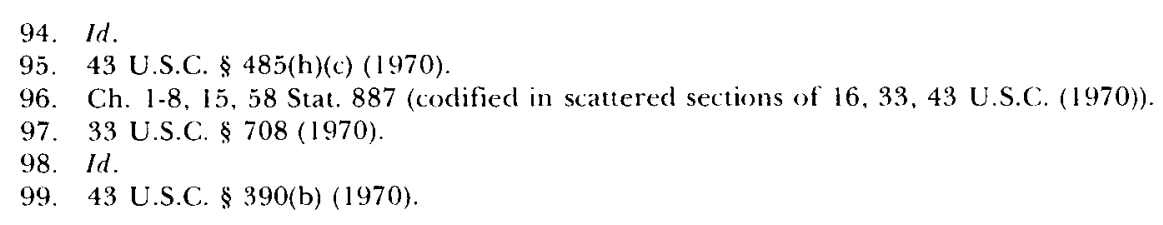


sponsibility of the federal government to the Indian tribes involved is not to be abrogated or diminished without specific congressional authorization to that effect and provision for just compensation for any taking of Indian rights.

This power of "taking" is rendered still more questionable by reason of the legislative history of the Boysen and Big Horn Reservoirs. ${ }^{100}$ The authorization for the Boysen Reservoir on the Wind River Indian Reservation followed protracted negotiations with the Arapahoe and Shoshone tribes living there. A careful review of the legislative history of the project and of the memorandum of understanding entered into by the tribes, the Secretary of the Interior, the Bureau of Reclamation, and the Bureau of Indian Affairs reveals no reference to the acquisition of the tribes' rights to the use of water or the subordination of these rights to the Boysen Dam Project. By the Act of July 18, 1952, ${ }^{101}$ Congress declared its purpose "to vest title in the United States to certain lands and interests in lands of the Shoshone and Arapahoe Indian Tribes of the Wind River Reservation and to provide compensation" totaling $\$ 458,000$. However, the Act did not affect any of the Indians' water rights, and indeed specifically provided that the conveyances and relinquishments shall be in accord with the above memorandum of understanding.

Moreover, the Supreme Court has held that the vested rights of a nonIndian water user may not be seized or disposed of by any agent of the United States. In United States \%. Gerlach Live Stock Company, the Justice Department argued that under the Commerce Clause the United States, in furtherance of a federal reclamation project, "does not have to compensate for destruction" of private rights to the use of water when exercising its "superior navigation easement."102 The Court, however, noted that the Reclamation Act of $1902^{103}$ required the Secretary of the Interior to give "full recognition to every vested right under" state law. ${ }^{104}$ Moreover, the Court took note that the Bureau of Reclamation had, in fact, paid compensation for rights to the use of water destroyed or impaired by the federal reclamation project. Without denying the superior rights of the federal government to control navigable streams the Court declared: "[W]e need not ponder whether, by virtue of a highly fictional navigation purpose, the Government could destroy the flow of a navigable stream and carry away its waters for sale to private interests without compensation to those deprived of them. We have never held that or anything like it . . ."105 Thus a federal agency may not take such property-including rights to the use of water acquired by prior appro-

100. S. Doc. Nos. 199, 247, 78th Cong., 2d Sess. (1944).

101. Ch. 946,66 Stat. 780 .

102. 339 U.S. at 736 .

103. 43 U.S.C. $\$ 383$ (1970).

104. United States v. Gerlach Live Stock Co., 339 U.S. at 734.

105. 339 U.S. at 737. 
priation $^{106}$ - without proper authorization and compensation. Similarly, it may be argued that in the absence of any authorization to purchase their reserved water rights, the Shoshone and Arapahoe tribes have retained those rights.

Further support for the Indians' water rights is found in the Court's interpretation of the 1868 treaty rights of the Shoshone. Referring to the government's fiduciary duty to the Indians, the Supreme Court, in Shoshone Tribe of Indians ฯ. United States said: "The power does not extend so far as to enable the Government 'to give the tribal lands to others, or to appropriate them to its own purposes, without rendering, or assuming an obligation to render, just compensation ... for that would not be an exercise of guardianship, but an act of confiscation." "107

Similar limitations on the exercise of federal power over Indian water rights is found in the laws and treaties bearing on the creation of the Big Horn Reservoir on the Crow Reservation of Montana. Like the Arapahoe and Shoshone, the Crow maintain that, under the Winters doctrine, their water rights were reserved under their 1868 treaty with the United States. But unlike the amicable settlement worked out with the Wyoming tribes, the Crows challenged the invasion of their reservation by the Bureau of Reclamation ${ }^{108}$ and demanded reasonable compensation for the Yellowtail Dam site. Congress did enact "taking" legislation, ${ }^{109}$ which authorized payment of just compensation for the right, title, and interest of the Crows in "lands" required for the dam. A series of subsequent court cases ${ }^{110}$ was addressed to the government's authority for taking the site, the extent of the right allegedly acquired, and the amount of just compensation owing.

The courts denied that the government held a "dominant servitude" or had "dominant control" over the Big Horn River within the Crow Reservation. Moreover, it was held that since the seizure by eminent domain of Crow property at the dam site was "for irrigation and recreation, as well as power production"11 an increased sum should be awarded over and above the

106. Nichols v. McIntosh, 19 Colo. 22, 34 P. 278, 280 (1893).

107. 299 U.S. 476, 497 (1937). Congress has explicitly acted to prohibit "the sale, disposition, lease or encumbrance of tribal lands, interests in lands, or other tribal assets without the consent of the tribe ..." 25 U.S.C. $\$ 476$ (1970).

108. Precipitating the controversy was the announcement on October 24, 1976 by the Reclamation Bureau's Assistant Secretary of Water and Power of an intention to sell Humble Oil and Refining Company 50,000 acre-feet of water from the Yellowtail Reservoir for industrial use. It was further proposed that a total of 500,000 acre-feet of water be similarly disposed from the Big Horn Reservoir. There was no indication that the interests or approval of the Crow Tribe would be taken into account. Memorandum Respecting Crow Indian Rights to the Use of Water in the Big Horn River and its Tributaries from William H. Veeder to Harrison Loesch, Assistant Secretary who was in charge of Indian Affairs, Aug. 12, 1968.

109. See Act of July 15, 1958, Pub. L. No. 85-523, 72 Stat. 361.

110. United States v. 5677.94 Acres of Land, 162 F. Supp. 108 (D. Mont. 1958); Crow Indian Tribe of Indians of Montana v. United States, Civil No. 214 (D. Mont., filed Oct. 1, 1963).

111. United States v. 5677.94 Acres of Land, 162 F. Supp. at 108. 
amount allowed in the legislation ${ }^{112}$ authorizing a taking and compensation. In effect, then, the Crow were subjected at most only to a partial taking for specific and limited purposes. They were not subjected to a total divestiture of their property interests in their Winters rights in the Big Horn River which could justify allocation and sale of their waters by the Bureau of Reclamation. As the Supreme Court has stated: "The taking by condemnation of an interest less than a fee is familiar in the law of eminent domain."113 This is certainly applicable in the Crow case.

\section{Conclusion}

Nowhere are the detrimental effects of piecemeal legislation relating to Indian rights more keenly felt than in the determination of water rights. Despite federal treaties and the existence of rights affirmed under Winters, the policy and practice of violation of their rights has continued to threaten the tribes of the Yellowstone River Basin. Pending litigation ${ }^{114}$ by the northern Cheyenne and Crow tribes to protect their rights in the Tongue and Big Horn Rivers may clarify certain issues relating to these tribes. ${ }^{15}$ However, the ultimate determination will probably turn on the application of federal policies formed in the face of the energy crises. Moreover, the historic reluctance of the Justice and Interior Departments to advocate Indian rights continues to render the protection of Indian reserved water rights difficult.

One issue is clear: It is detrimental to all concerned to persist in formulating grandiose schemes for developing coal-related industries in the region on the basis of highly misleading water supply projections that totally disregard the present and future demands on alleged firm water supplies. ${ }^{116}$ Federal agencies often fail to present accurately the facts concerning the highly fluctuating water supplies and the needs of those already holding title of vested rights, either Indian or non-Indian. Mistakes in these estimates have disastrous consequences for local water users who are virtually without remedies once water has been committed by powerful political forces to uses which exceed anticipated supplies.

For a period of time a moratorium was imposed by the Secretary of the

112. Act of July 15, 1958, Pub. L. No. 85-523, 72 Stat. 361

113. United States v. Cress, 243 U.S. $316,328-29$ (1916).

114. The Northern Cheyenne Tribe v. Tongue River Water Users Assoc., Civil No. 76-6 (D. Mont., filed Jan. 30, 1975); United States v. Tongue River Water Users Assoc., Civil No. 75-20 (D. Mont. filed Mar. 7. 1975); United States v. Bighorn Line Canal, Civil No. 75-34 (D. Mont., filed Apr. 17, 1975).

115. Of particular importance is the question whether the Indians are restricted to relief in the state of Montana or may also be granted relief in Wyoming, through whose territory their waters flow. See Willey v. Decker, 11 Wyo. 496, 73 P. 210 (1903).

116. See Report on Montana-Wroming Aqueducts, supra note 1. See also U.S. Dep't of the INTerior, Water for ENergy MaNagement Team, Report oN Water for ENergy iN the Northern Great Plains Area With Emphasis on the Yellowstone River Basin $1-7$ (1975). 
Interior on sales of the water of the Big Horn River by the Bureau of Reclamation. Congress, too, has held comprehensive hearings on rights to the use of water in the entire Upper Missouri River Basin. ${ }^{117}$ Appropriate legislation would, of course, go a long way toward resolving the complex factual, legal, and economic issues that have been raised by alternative energy programs affecting the Yellowstone River Basin. However, the suspension, early in 1976, of the moratorium on coal leasing increased the pressure to invade the rights of the Crow and Wind River Indians of the Big Horn as well as those of the Cheyenne on the Tongue River. ${ }^{18}$ Even as comprehensive legislation is entertained and the Secretary of the Interior's promise to protect the interests of all western Indians is put to the test, the policies and principles established should not fail to conform to the concepts of water law reviewed here-concepts which are deeply rooted in the nation's history and Constitution.

117. Hearing set for June 26, 1975, reset for July 18, 1975. See also the discussion of these issues in the nomination proceedings of Interior Secretary Stanley K. Hathaway and particularly statements of Senator Metcalf in Hearings on the Nomination of Stanley $K$. Hathaway to be Secretary of the Interior Before the Senate Comm. on Interior and Insular Affairs. 94th Cong., 1st Sess. 82-93 (1975).

118. On the new regulations affecting the lease of federal lands for coal mining see 43 C.F.R. $\S 3040$, as amended, 83041,49 Fed. Reg. $20252-273$ (1976). See also N.Y. Times, May 12, 1976, at 68 , col. 1. The Supreme Court also held that the Interior Department does not have to prepare an environmental impact statement on the regional effects on coal development in the northern Great Plains. Kleppe v. Sierra Club, 44 U.S.L.W. 5104 (U.S. June 28, 1976). 